\title{
The Application of Export Credit Insurance Policy in Regional Economic and Trade Cooperation--Taking Local Governments in Yunnan for Example
}

\author{
Wang Wenhui $^{1}$ He Youlin ${ }^{2}$ \\ ${ }^{1}$ Public Management School, Yunnan University of Finance and Economics \\ (0871169@163.com) \\ 2Yunan Branch, China Export \& Credit Insurance Corporation (heyl@sinosure.com.cn)
}

\begin{abstract}
As well as posing a challenge to the management methods and means of local governments, the rapid development of regional economy and trade has presented an opportunity of reform. In China, Yunnan borders on many countries including Vietnam, Laos, and Burma. Thus, it is an important gateway for China to carry out regional economic and trade cooperation with Southeast Asia and South Asia. This paper, typically exemplified by the Export Credit Insurance Policy in Yunnan, analyzes and explains local governments' challenges and solutions in regional economic cooperation and competition.
\end{abstract}

Keywords: Regional Economic and Trade Cooperation, Export Credit Insurance Policy, Local Governments

\section{Introduction}

Due to mutual influence, transmission, and penetration between internal and external economy as well as the requirements of international trade, regional economic trade is faced with the policy intervention conducted by sovereign governments in inter-state trade activities and the corresponding policy effect. The competition in international market has already evolved into the competition of overall national strength, with competition upgrading from corporate level to government level. In regional economic and trade cooperation as well as competition, the local governments which directly get involved in regional economic and trade corporation are playing an increasing role, besides the decisive role of the central government of sovereign state. This paper, typically exemplified by the Export Credit Insurance Policy in Yunnan, analyzes and explains local governments' challenges and solutions in regional economic cooperation and competition.

The research of regional cooperation assigns more importance to central policies of sovereign states but less importance to the role of local governments. Besides, in regional economic corporation, researchers pay more attention to the overall economic policies, while they are required to detail the research on specific economic policies. This paper analyzes the development of regional economy and trade from the aspects of local governments and export credit insurance policy.

\section{Export Insurance Policy in Regional Economic and Trade Cooperation of Yunnan}

Since 1978, Yunnan has commenced the practice of "neighbor-based, ASEAN expansion, South Asia exploitation, world facing”. This not only fully exploits the natural advantages of geographic proximity, ethnic homology and cultural similarity with neighbors, but also promotes and deepens multi-regional cooperation and exchange with Southeast Asia and South Asia. Yunnan takes an active part in the construction of China-ASEAN free trade area in various ways. Meanwhile, it also advocates and promotes the positive cooperation of Lancangjiang River-Mekong River sub-region (GMS) and BCIM regions. Additionally, it has successively established and participated in the international cooperative organizations such as Yunnan- North Thailand working group, economic corridor cooperation conference of Yunnan and four provinces and cities in Vietnam, joint working group of Yunnan and four provinces in Vietnam, Yunnan-North Laos working group, Yunnan-Burma cooperative business forum, and Mekong Institute, developing into the independent cooperative subject in regional economic and trade cooperation.

As an important policy widely applied by worldwide sovereign states to facilitating the development of foreign trade and economy, export credit insurance proves to be the trade facilitating measure that conforms with WTO 
rules and international practice, as well as the extension of worldwide public financial functions. In Foreign Trade Law of the People's Republic of China, export credit insurance is determined as one of three major facilitating policies that develop foreign trade. ${ }^{1}$ To a great extent, the situation of export credit insurance reflects the attitude of central governments and local governments toward export policy and regional economic and trade cooperation policy. Since Chinese government brought in export credit insurance mechanism, especially since 2011 when China Export \& Credit Insurance Corporation was founded, export credit insurance has exerted an increasingly obvious effect on Chinese policy about foreign trade and economic development.

In 2010, governmental departments such as Department of Finance of Yunnan Province and Department of Commerce of Yunnan Province fully played the role of guidance and coordination, positively constructed the platform favorable for the local enterprises to fully apply export credit insurance policy, and encouraged local enterprises to fully employ export credit insurance policy. In addition, they offered premium support for enterprises to insure export credit risk. They supported $80 \%$ of provincial agricultural exports, $50 \%$ of provincial high-tech, mechanic and electronic exports, and 20\% of other provincial exports. Supportive policy has effectively advanced the rapid growth and structure adjustment of provincial foreign trade, which has thus created a powerful policy environment for Yunnan Province to participate in regional economic and trade cooperation ${ }^{2}$.

\section{The Challenges and Problems that Yunnan Faces in Regional Economic and Trade Cooperation}

Nowadays, with a growing number of uncertainties, the world faces the increasing pressure of economic downturn, the complicatedly worsening situation, the shrinking demand of traditional export markets such as the United States, Europe, and Japan, and the pent-up demand arising from the slowing-down economic growth in developing countries.

Against this backdrop, foreign trade and economic development in Yunnan is faced with an increase in difficulty and challenge, besides an obvious increase in risks. In terms of foreign trade, export enterprises are concerned about foreign exchange risks, not daring to accept an order. In the meanwhile, a mass of export enterprises are beset by difficulty in financing, without ability to accept an order. In the process of exploiting new overseas market, export enterprises show inadequate understanding on overseas purchasers, thus restricting the diversification of export market and overseas purchasers, and affecting the optimization and upgrade of Yunnan export structure. In the category of foreign investment, investors worry that their own strength will have difficulty in controlling the political risks such as default of foreign governments, collection risk, restraints on exchange, war, and political violence, which often accompanies with the difficult financing problems involving a large sum of money. With regard to foreign project contracting and the export of large complete equipment, contractors are fearful of proprietor's failure in settling the due payment and the financing problem of "contracting with self-owned capital". These problems, laying restraints on regional economic and trade cooperation in Yunnan, must be properly addressed. They cannot be resolved by enterprises only, so it is necessary for government to intervene via effective policy means.

\section{Yunnan Employs the Policy Measures via which Export Credit Insurance Advances Regional Economic and Trade Development}

Songwei Company is a privately-run enterprise involved in processing and sales of vegetables and agricultural byproducts. Based on export credit insurance, Songwei Company exploits the emerging markets boldly, sorts out and updates purchaser's credit information in time, and sets up classified management system for overseas customers. Additionally, it adopts documentary bills under the export credit insurance policy, getting new bank loans of over 36 million Yuan. In 2010, it broke $\$ 30$ million of export volume, ranking first in Yuxi.

In the context of internationalization and regionalization, Yunnan Province expedites the development of foreign economic and trade cooperation. In the presence of the god-given opportunity of expanding international operation, enterprises are also exposed to the problems such as international risk, difficulty in financing and market exploitation problem. As an effective policy instrument, export credit insurance has offered optimum policy support for enterprises like Songwei.

\subsection{Constructing Risk Protection Platform to Cope with Foreign Risks}

By way of export credit insurance, government provides prior, in-process and subsequent credit risk management service for export enterprises. In advance, it helps enterprises to obtain related information about target market and counterparty, aiming to prevent risks beforehand. During the 
risk, it renders professional risk management service, as well as offers risk early-warning information and risk disposal opinions, so as to assist enterprises with the prevention of operational risks. After the foreign exchange risks take place, timely compensation will contribute to the protection of enterprises' operating results and capacity. The specific policy operations are consisted of following aspects:

4.1.1 In reference to the foreign project contracting and the capital exports such as large complete equipment with the credit period of one to twelve years, medium-and long-term export credit insurance (comprised of export buyer's credit insurance and export seller's credit insurance) can be utilized to take foreign exchange risks. Export buyer's credit insurance provides protection against repayment risks for lending banks, while export seller's credit insurance provides export enterprises with protection against foreign exchange risks about business cooperation.

4.1.2 The overseas investment insurance business of export credit insurance can take the possible political risks for the enterprises, including government default, collection, war, restraints on exchange, etc. In addition, it supports Yunnan enterprises to "go global", particularly to the neighbors such as Burma, Cambodia, Laos, and Vietnam, invest in the exploitation of the fields such as electric power, mineral resource and agriculture, and take part in international competition in an active and flexible way.

The construction of the platform for protection against risk and the export credit insurance can aid Yunnan enterprises in seizing the opportunity arising from bridgehead strategy, enhancing the confidence in export expansion and "go global" development, and effectively addressing the problems such as foreign risks and the fear of accepting orders and projects. Meanwhile, export credit insurance underwrites the business which is of high risks and long period and which enterprises dare not undertake without protection against risks. This has directly spurred foreign trade development as well as the implementation of foreign trade investment and cooperation projects, which has thus driven provincial economic and trade development and regional cooperation.

\subsection{Constructing Financing Promotion \\ Platform to Solve Financing Problems}

CBRC (China Banking Regulatory Commission) explicitly stipulates "when the bank calculates capital adequacy ratio, China Export \& Credit Insurance Corporation provides $0 \%$ as the loan risk weight of policy credit insurance. ....when making loan classification, the loans underwritten by China Export \& Credit Insurance Corporation exceed 90 days, but still within waiting period stipulated by the contract can be classified as normal loans". "This is beneficial for the governments to share structural risks with export credit insurance, urge enterprises to obtain financing support, and innovate in financing modes together with banks.

4.2.1 the business of insurance policy financing is implemented. By way of short-term export credit insurance, export enterprises sign tripartite Indemnity Transfer Agreement with banks and export credit insurance institutes under the condition of no guarantee, no pledge, and not occupying enterprise's original credit line in the bank. After export declaration, enterprises can have their trade right of credit protected and thus ensure the safety of bank's credit funds. Then, the bank will offer financing support, with the specific forms including short-term financing of outward bill, coordinating with banks to handle L/C packing credit, etc.

4.2.2 enterprises are supported to achieve pre-export financing via order financing, which will thus relieve enterprises' capital pressure. Pre-shipment insurance and buyer's default insurance included in export credit insurance support enterprises to acquire order financing and L/C packing credit, obtain financing support before shipment, make up the order and start production, quicken capital circulation, and expand business scale.

\subsection{Constructing Information Consulting \\ Platform to Resolve the Problem of Market Exploitation}

In terms of supporting foreign trade development, government helps export enterprises to better understand credit information about such aspects as overseas buyer's registration, operation, finance, lawsuit, and management via information consulting service of export credit insurance. This intends to evade risks caused by overseas buyers. See below for specific methods: First, through investigation and evaluation on enterprises' overseas buyers, the main customer base is classified to coordinate with and help the qualified enterprises; meanwhile, the customer management system is set up to guide the enterprises in doing more deals with customers that are of strong payment ability and good credit standing, as well as adopting more settlement methods. The transaction scale is supposed to be maintained for the enterprises with average credit. For the customers with poor payment ability and credit, it is necessary to 
adopt cautious attitude, and reasonably control account period and the scale of account receivable. Second, there is a need to provide a basis for enterprises to make decisions, assist enterprises in optimizing and adjusting the export scale and settlement methods of overseas buyers, and effectively input the limited funds and operating resources into the aspects of key markets and customers. This will thus optimize enterprise's business structure and capital application.

The construction of information consulting platform and the export credit insurance can aid enterprises in effectively and quickly integrating with international market, expedite the implementation of market diversification strategy, and address the problem of market exploitation. Government's application of such policy means proves to be positive and effective.

\section{Conclusions}

To make the export credit insurance fully play the policy function as a policy tool, the key aspects comprise the guidance and support of governmental departments, the active participation of foreign trade enterprises, and the support and coordination of bank, dealer association, and media. In the context of regionalization, the author comes up with following suggestions to use this policy instrument in a more effective way.

\subsection{It is suggested that governmental departments should value and support export credit insurance more.}

Governmental departments, especially business competent departments at all levels, should highly value export credit insurance which is an important facilitating policy for foreign economy and trade. Besides, they are also supposed to improve the environment and condition adopted by enterprises to utilize insurance policy as well as constructing the platform favorable for enterprises to fully apply export credit insurance policy. Additionally, governmental departments are expected to cement coordination with export credit insurance institutes, and formulate or improve the specific measures of developing export credit insurance. Meanwhile, they are needed to deliver necessary support for export credit insurance institutes in aspects of understanding enterprise demand and helping enterprises with the problems about risk, financing and market exploitation. Also, they should guide and encourage enterprises to make good use of export credit insurance policy.
5.2 It is advised that foreign trade enterprises should apply export credit insurance policy in a positive way and coordinate related aspects.

Also, it is proposed that enterprises should positively take advantage of the platform for protection against risks, financing promotion platform and information consulting platform of export credit insurance according to their own actual condition. Meanwhile, they are required to firmly seize the opportunities brought by regionalization and bridgehead strategy and effectively speed up the development of export business and "go global". Additionally, it is suggested that all banks and export credit insurance institutes should deepen cooperation and jointly establish a financing platform for foreign trade enterprises. Moreover, it is advised that news media should spend more efforts in propagandizing export credit insurance policy, which will allow enterprises to make better use of this policy financial instrument.

5.3 It is proposed that export credit insurance institutes should make more efforts to render high-quality and efficient services for foreign economic and trade enterprises, and further lower enterprises' insurance cost.

As an effective policy instrument, export credit insurance can capacitate government to fully play the function of coordination and cope with the challenges presented by internationalization and regionalization for government management under new economic situation. The flexible policy instrument provides enterprises with policy platform, reinforces enterprises' competitiveness and enables enterprises to participate in regional economic and trade cooperation in a more vigorous way.

\section{References}

[1] Foreign Trade Law of the People's Republic of China: "The state shall adopt various promotion measures to develop foreign trade including issuing of import and export credit, export credit insurance, and setting up of export rebates”, 2004, article53.

[2] data source : author investigation

[3] Cited from On Approval for the Underwritten Loan Risk Weight and Risk Classification of China Export \& Credit Insurance Corporation Issued by China Banking Regulatory Commission (Yinjianbanfa (2005) No.150) 